1. BSc. MBBS, FCPS

Registrar Urology

Teaching DHQ Hospital Gujranwala/

Gujranwala Medical College.

2. MBBS, MS (Urology)

Associate Professor Urology

Teaching DHQ Hospital Gujranwala/

Gujranwala Medical College.

3. MBBS

Medical Officer Urology

Teaching DHQ Hospital Gujranwala/

Gujranwala Medical College.

4. MBBS, FCPS

Postgraduate Resident Urology

Teaching DHQ Hospital Gujranwala/

Gujranwala Medical College.

5. MBBS, MS (Urology)

Assistant Professor Urology

Teaching DHQ Hospital Gujranwala/

Gujranwala Medical College.

Correspondence Address:

Dr. Rao Nauman Ali

Registrar Department of Urology

DHQ University Teaching Hospital

Gujranwala, Pakistan.

drnoumanali@gmail.com

Article received on:

04/07/2019

Accepted for publication:

31/10/2019

\section{A CASE REPORT ON CONTINENT ISOLATED MALE EPISPADIAS.}

Rao Nouman Ali ${ }^{1}$, Khalid Hussain ${ }^{2}$, Hassam Khalid ${ }^{3}$, ZainYasin ${ }^{4}$, Attiq-ur-Rehman ${ }^{5}$

\begin{abstract}
Epispadias is a rare congenital anomaly in which the urethral opening is on the dorsal surface of penis. Its incidence is 1 in 117000 newborn males and 1 in 484000 in newborn females. Its etiology is considered as because of failure of medial migration of mesenchyme between the ectodermal and endodermal layers of cloacal membrane due to premature rupture of cloacal membrane. Epispadias often presents as exstrophy epispadias complex, a wide spectrum of abnormalities that consist of classic bladder exstrophy, Epispadias and cloacal exstrophy. This case was not a part of exstrophy epispadias complex and it was an isolated continent epispadias which is extremely rare and it was managed with Cantwell Ransley epispadias repair technique.
\end{abstract}

Key words: $\quad$ Cloacal Membrane, Epispadias, Exstrophy.

Article Citation: Ali RN, Hussain K, Khalid H, Yasin Z, Attiq-ur-Rehman. A case report on continent isolated male epispadias. Professional Med J 2020; 27(6):13201322. DOI: 10.29309/TPMJ/2020.27.06.3899

\section{INTRODUCTION}

Epispadias is associated with many coexisting congenital conditions importantly vesicoureteric reflux, exstrophy of bladder, Urinary incontinence and inguinal hernias. ${ }^{1}$ Mostly it presents as exstrophy epispadias complex. Incidence of coexisting VUR is $30-75 \%$ and of inguinal hernia is $33 \%$. Other less common congenitalissues reported are renal and colorectalanomalies. ${ }^{2}$

Epispadias is usually recognized at birth in male child but in females it may go unrecognized, until the child experiences persistent urinary incontinence after toilet training or urinary tract infections.

Epispadias has vast range of variations on physical examination e.g appears as displaced meatus or as open urethral plate visible on dorsum of phallus in male child while in female child it presents as bifid clitoris and Mons pubis depressed and covered in glabrous skin. ${ }^{3}$ Epispadias is a clinical diagnosis but most of the times plain $\mathrm{x}$ ray is required to assess orientation of pelvic bones and ultrasonography to assess presence or absence of kidneys and hydronephrosis. Voiding cystourethrogram to assess bladder capacity and vesicoureteric reflux. ${ }^{4}$

Managing Epispadias is a great challenge, its management is mainly surgical involving bladder closure, urethral reconstruction and osteotomies if pubic diastasis is present, further surgery may be necessary to correct complications of initial surgeries or to achieve improved cosmesis or compete continence. ${ }^{5}$

\section{CASE REPORT}

In this case study a 27 year male presented with history of upward stream of urine from a abnormally placed urethral meatus since childhood. On examination it was not associated with exstrophy of bladder. On investigations such as ultrasonography there was no renal agenesis or hypoplasia or any hydronephrosis. On voiding cystourethrogram there was no vesicoureteric reflux. Cystoscopy was done to asses bladder capacity which was $300 \mathrm{ml}$ with normal ureteric 
orifices and no trabeculations. Patient was continent and after his complete evaluation his surgery was planned. Goal of surgery was reconstruction of external genitalia for optimal functional and cosmetics results.

Reconstruction was done through modified Cantwell-Ransley repair involving tubularization of intact urethral plate and transposition of urethra ventral to corpora cavernosa. After repair his catheter was removed after 2 weeks of surgery and patient was followed for 6 monthstonotifyanypostsurgicalcomplication.

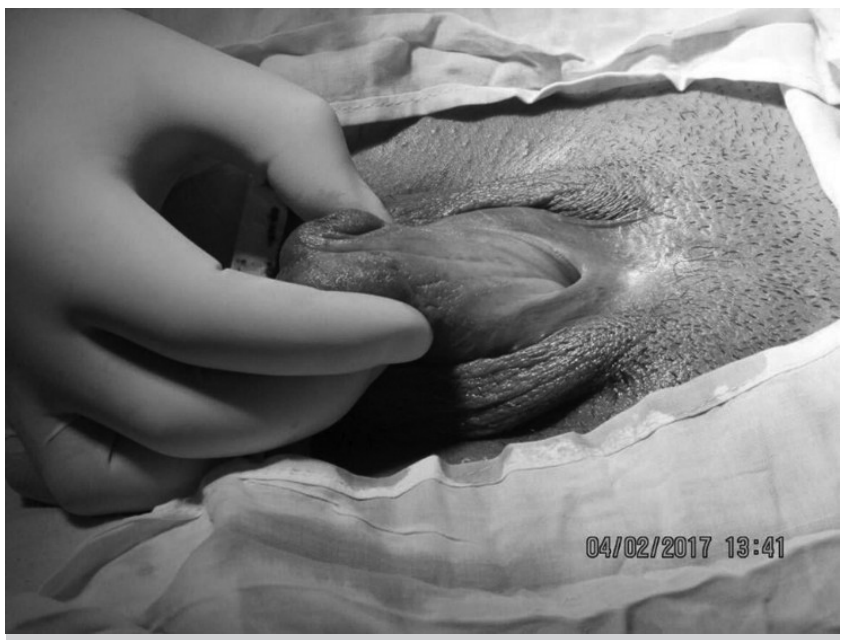

Figure-1. Pre-operative dorsally placed urethral meatus.

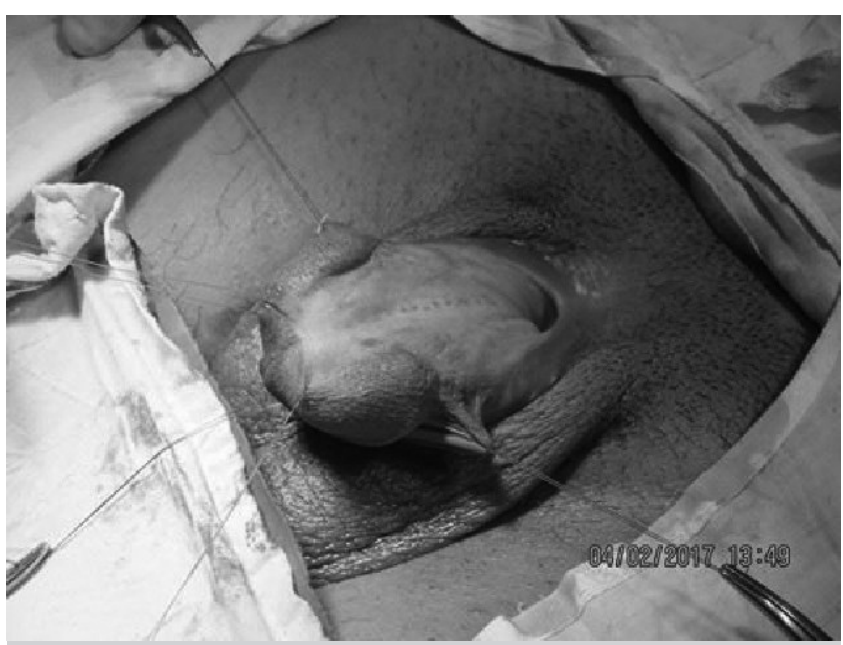

Figure-2. Peri-opertaive dorsally placed urethral meatus stay sutures applie.

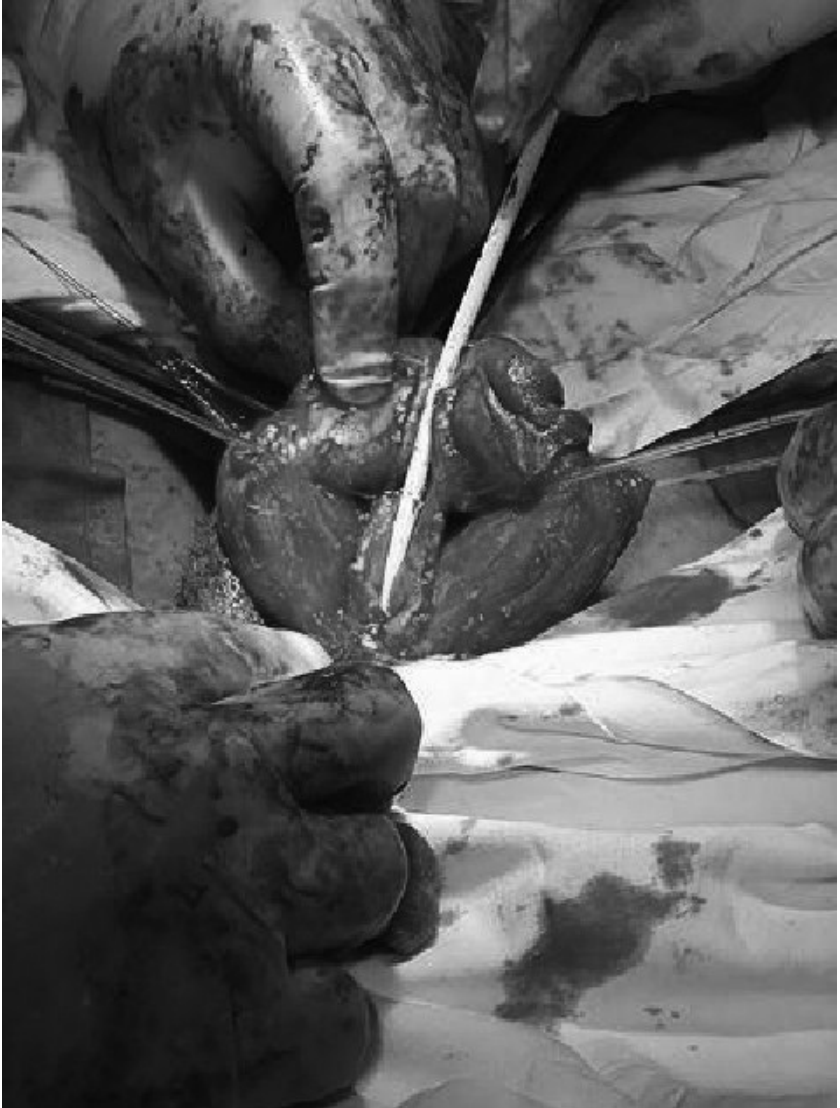

Figure-3. Mobilization of corporal bodies over foleys catheter.

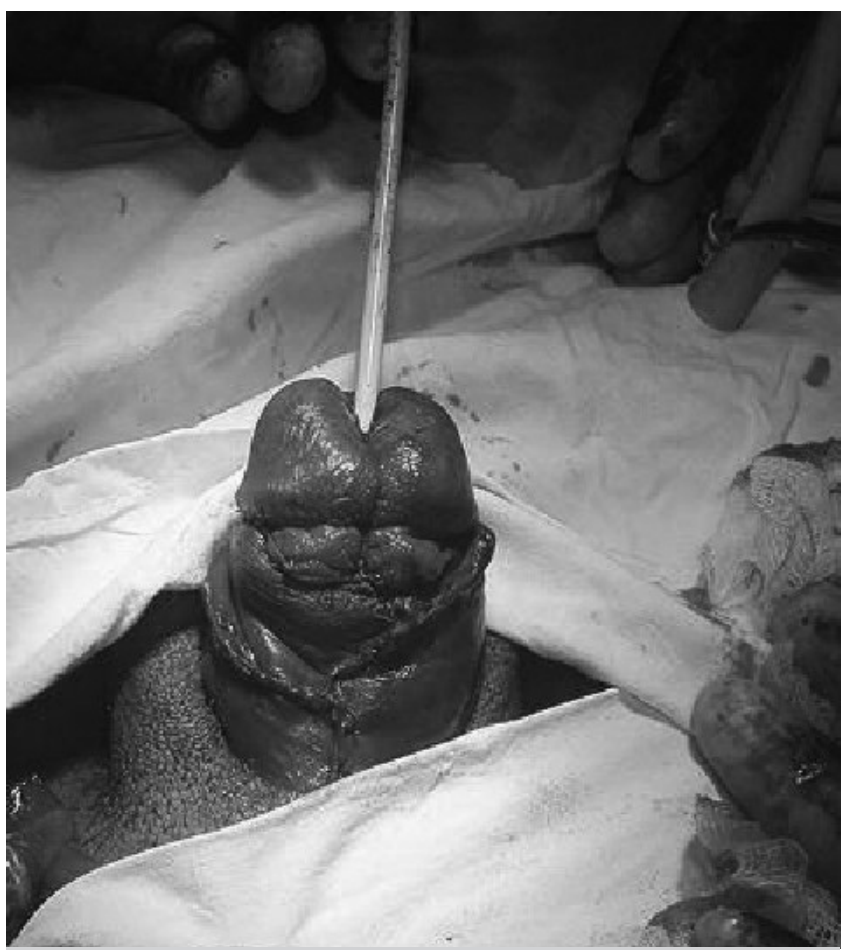

Figure-4. Post-Operative final appearance after modified cantt well ransley repair. 


\section{DISCUSSION}

Isolated continent epispadias is a very rare congenital anomaly. Its presentation ranges from an isolate urethral defect to severe bladder exstrophy with concomitant renal, inguinal and colorectal anomalies.

Male and female epispadias has variety of appearances on physical examination. In male child common appearances on examination are in the form of displaced meatus or as open urethral plate. In female epispadias present as bifid clitoris and labia minora poorly developed and terminated anteriorly at clitoris. ${ }^{6}$ Diagnosis is clinical and further investigations are required to inquire concomitant abnormalities of bladder, pubic bones and kidneys. Ultrasound demonstrates the details of status of kidneys and voiding cystourethrogram is required for possibility of vesicoureteric reflux. Cystoscopy is needed to know the bladder capacity, condition of ureteric orifices and urethral anatomy. ${ }^{7}$ Management goals are case dependent. Majority of cases require correction of VUR and Maintenance of a low pressure system and to achieve urinary continence.

Copyright@ 31 Oct, 2019.

\section{REFERENCES}

1. Higuchi T., Holmdahl G., Kaefer M., et al. International consultation on urological diseases: Congenital anomalies of the genitalia in adolescence. Urology. 2016; 94:288-310. doi: 10.1016/j. urology. 2016.03.019. [PubMed] [CrossRef] [Google Scholar].
2. Carrasco A., Jr., Vemulakonda V. M. Managing adult urinary incontinence from the congenitally incompetent bladder outlet. Current opinion in urology. 2016; 26(4):351-356. doi: 10.1097/MOU.0000000000000296.

[PubMed]

[CrossRef] [Google Scholar].

3. Inouye BM, Tourchi A, Di Carlo HN, Young EE, Mhlanga J, Ko JS, et al. Safety and efficacy of staged pelvic osteotomies in the modern treatment of cloacal exstrophy. J Pediatr Urol. 2014 Dec. 10 (6):12448. [Medline].

4. Ko JS, Lue K, Friedlander D, Baumgartner T, Stuhldreher P, DiCarlo HN, et al. Cystectomy in the pediatric exstrophy population: Indications and outcomes. Urology. 2018 Jun. 116:168-171. [Medline].

5. Leclair MD, Faraj S, Sultan S, Audry G, Héloury Y, Kelly $\mathrm{JH}$, et al. One-stage combined delayed bladder closure with Kelly radical soft-tissue mobilization in bladder exstrophy: Preliminary results. J Pediatr Urol. 2018 Dec. 14 (6):558-564. [Medline].

6. Ben-Chaim J, Hidas G, Wikenheiser J, Landau EH, Wehbi E, Kelly MS, et al. Kelly procedure for exstrophy or epispadias patients: Anatomical description of the pudendal neurovasculature. J Pediatr Urol. 2016 Jun. 12 (3):173.e1-6. [Medline].

7. Leclair MD, Villemagne T, Faraj S, Suply E. The radical soft-tissue mobilization (Kelly repair) for bladder exstrophy. J Pediatr Urol. 2015 Dec. 11 (6):364-5. [Medline].

8. Chua ME, Ming JM, Fernandez N, Varghese A, Farhat WA, Bagli DJ, et al. Modified staged repair of bladder exstrophy: A strategy to prevent penile ischemia while maintaining advantage of the complete primary repair of bladder exstrophy. J Pediatr Urol. 2018 Sep 25. [Medline].

\begin{tabular}{|c|c|c|c|}
\hline \multicolumn{4}{|c|}{ AUTHORSHIP AND CONTRIBUTION DECLARATION } \\
\hline Sr. \# & Author(s) Full Name & Contribution to the paper & Author(s) Signature \\
\hline 1 & Rao Nouman Ali & Researcher & 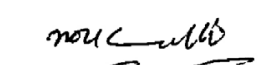 \\
\hline 2 & Khalid Hussain & $\begin{array}{l}\text { Making performa \& Data } \\
\text { collection }\end{array}$ & \\
\hline 3 & Hassam Khalid & Supervisor & \\
\hline 4 & ZainYasin & Proof reading & \\
\hline 5 & Attiq-ur-Rehman & Statistical Analysis. & \\
\hline
\end{tabular}

